\title{
The Impact and Influence of Rankings on the Quality, Performance and Accountability Agenda
}

\author{
Ellen Hazelkorn \\ Technological University Dublin, ellen.hazelkorn@tudublin.ie \\ Andrew Gibson \\ Technological University Dublin, andrew.gibson@tudublin.ie
}

Follow this and additional works at: https://arrow.tudublin.ie/cseroth

Part of the Adult and Continuing Education Commons

\section{Recommended Citation}

E. Hazelkorn and A. Gibson (2018) "The Impact and Influence of Rankings on the Quality, Performance and Accountability Agenda" in E. Hazelkorn, H. Coates and A. McCormick (eds.) Research Handbook on Quality, Performance and Accountability, Cheltenham: Edward Elgar.

This Book Chapter is brought to you for free and open access by the Centre for Social and Educational Research at ARROW@TU Dublin. It has been accepted for inclusion in Other resources by an authorized administrator of ARROW@TU Dublin. For more information, please contact arrow.admin@tudublin.ie, aisling.coyne@tudublin.ie,gerard.connolly@tudublin.ie.

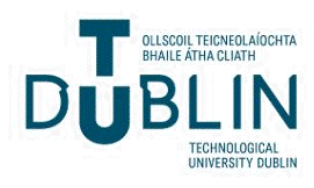


Hazelkorn, E., Coates, H. and McCormick, A.C. (Eds.) (2018) Research Handbook on Quality, Performance and Accountability in Higher Education, Edward Elgar Publishing. http://www.eelgar.com/shop/research-handbook-on-quality-performance-and-accountability-in-higher-education

\section{The Impact and Influence of Rankings on the Quality, Performance and Accountability} Agenda

Ellen Hazelkorn and Andrew Gibson

\section{Introduction - the Rise of Rankings}

When global rankings first appeared in 2003, rankings in general were little known despite the fact that collecting statistical information on individual academic institutions had begun by the U.S. Bureau of Education in the late $19^{\text {th }}$ century (Snyder, 1993). This was followed by various attempts to measure and compare the performance of faculty members and correspondingly their institutions by focusing on the schooling and characteristics of birth of such "Geniuses" or "Great Men". This early focus on "distinguished persons" dominated rankings to the 1950s but effectively excluded most public universities, such as Land Grant universities, because they were newer institutions with a different mission than the older private universities.

By the second half of the $20^{\text {th }}$ century, rankings were becoming more sophisticated and numerous. The appearance of the Science Citation Index in 1961 and the Social Sciences Citation Index in 1966 enabled rankings to "skip survey methodologies" (Usher, 2016). This gave them the appearance of independence and scientific rigour. The emergence of U.S. News and World Report College Rankings in 1983 marked a turning point, transforming rankings from an individual-scholarly pursuit into a consumer product. Coinciding with the massification of higher education, greater student mobility, and the acknowledged link between qualification, career, salary and lifestyle, these early endeavours paved the way for the emergence of user-oriented university rankings - which now exist worldwide. Over the decades, rankings have become a significant actor on the higher education landscape, used around the world by policymakers and decision-makers at government and higher education institution (HEI) level, as well as myriad stakeholders including students. In varying ways, and depending upon local context, global rankings have eclipsed national rankings in their influence and impact.

This chapter contextualises the rise and influence of ranking within broader discussions of quality, performance and accountability. It explores the influence of rankings on the quality debate, on measuring and comparing performance, and on the politicisation of the accountability agenda. Section 2 provides an overview on rankings, while Section 3 situates rankings within the discourse and politics of the accountability agenda. Section 4 looks at the influence and role of rankings at the institutional level. Section 5 reviews some recent developments, and at alternative rankings and alternatives to rankings, and argues that the influence of rankings extends beyond their technical characteristics. 
Hazelkorn, E., Coates, H. and McCormick, A.C. (Eds.) (2018) Research Handbook on Quality, Performance and Accountability in Higher Education, Edward Elgar Publishing. http://www.e-

elgar.com/shop/research-handbook-on-quality-performance-and-accountability-in-higher-education

\section{Tracing the Growing Influence of Rankings}

There are four main periods in the history of rankings, each reflecting the social and political characteristics of their time:

- Phase 1 (1900-1950s): educational origins of "eminent men" in excellent universities, later considering broader questions of institutional excellence;

- Phase 2 (1959-2000): rise of commercially-driven rankings focused on reputational factors, in response to growing massification, student mobility and marketization of higher education;

- Phase 3 (2003-): advent of global rankings reflecting globalisation and global competition, and strengthening of the international academic and professional labour market;

- Phase 4 (2008-): arrival of supra-national rankings in response to growing concerns about the need to regulate and monitor quality, credentials and the growing number of trans-national and private providers.

Today, there are three main - or most widely referenced - global rankings within a larger group of approximately ten ${ }^{1}$ : Academic Ranking of World Universities (ARWU) (Shanghai Jiao Tong University, China) from 2003 onwards, QS World University Rankings (Quacquarelli Symonds, UK) from 2010 onwards, and THE World University Ranking (Times Higher Education, UK) from 2010 onwards. The European Union has developed its own alternative ranking, U-Multirank. In addition to ARWU, most of the well-used global rankings focus on predominantly research.

The rise of global rankings has been swift and remarkable, with one government likening the promoter of THE to "the education secretary of the world" (Baty, 2016, 4). Notwithstanding methodological problems and concerns about perverse influence and effects, global rankings have been a game-changer. They helped push higher education and research investment up the political and policy agenda. They also forced HEls, faculty and policymakers to confront concerns about quality, performance and accountability in ways which had previously garnered less attention or been ignored. Their significance lies in being able to affect the competitive standing of universities and countries, and act as a beacon for mobile capital and talent (Standards \& Poor, 2016). Ultimately, they have succeeded in transforming the characteristics of the top-100 universities into idealised attributes for all HEls, and the concept "world-class" into an ambition, a strategy and a language for nations and universities.

Although global rankings purport to measure higher education quality, they focus on a limited set of attributes for which (internationally) comparable data is available. Some observations are worth making. 
Hazelkorn, E., Coates, H. and McCormick, A.C. (Eds.) (2018) Research Handbook on Quality, Performance and Accountability in Higher Education, Edward Elgar Publishing. http://www.eelgar.com/shop/research-handbook-on-quality-performance-and-accountability-in-higher-education

1) Global rankings compare HEls using different indicators, weighted differently to reflect their relative importance. Scores are then aggregated to a single number. This simplicity is their success. With this approach, rankings have placed higher education within a wider comparative and international framework.

2) Global rankings claim to "compare the world's top universities" (Quacquarelli Symonds World University Rankings, 2017) or "provide the definitive list of the world's best universities evaluated across teaching, research, international outlook, reputation and more" (Times Higher Education, 2017), but in truth, global rankings measure a very small sub-set of the total $18,000 \mathrm{HEls}$ worldwide. Many of the indicators focus on inputs which are strongly correlated to wealth (e.g. institutional age, endowments/philanthropy or tuition), as a proxy for educational quality (Pike, Kuh, McCormick, Ethington, \& Smart, 2011).

3) Global rankings primarily measure research and ignore teaching. Fully 70\% of QS indicators focus on research and research-related factors, such as PhD awards, research income, citations, and so on; Times Higher Education rankings allocate over 90\%, while ARWU devotes 100\%. QS - along with U.S. News and World Report-use the staff-student ratio as a proxy for educational quality. However, due to different methods by which to classify academic staff and students, and different practices in different countries and institutions, this is an unreliable indicator of educational quality (Borden, 2011).

4) Both QS and THE use reputational surveys, the former assigning $50 \%$ and the latter $33 \%$ of the total score, as a means of assessing how an institution is valued by its faculty peers and key stakeholders. This methodology is widely criticized as overlysubjective, self-referential and self-perpetuating in circumstances where a respondent's knowledge is limited to that which they already know, and reputation is conflated with quality or institutional age (Bowman \& Bastedo, 2011). Reputational surveys also rely on a very small number of responses.

5) The absence of meaningful international datasets and agreed definitions has led to the prolific use of questionable proxies and considerable concern around the robustness of the data. Whether consciously or not, data can be prone to manipulation, over-exaggeration or simple error (e.g. Cloud \& Shepherd, 2006; Holmes, 2017). And, it's not certain ranking organisations have the capacity to fully scrutinise the data (Baty, 2016b). National rankings are better in this respect although problems still persist (Bekhradina, 2016).

Critics might have thought censure would have curtailed their appeal, but this has not happened. Instead, rankings have fuelled the use of indicators for policy-making, monitoring and strategic decision-making, with their usage interpreted as a gauge of new public 
Hazelkorn, E., Coates, H. and McCormick, A.C. (Eds.) (2018) Research Handbook on Quality, Performance and Accountability in Higher Education, Edward Elgar Publishing. http://www.e-

elgar.com/shop/research-handbook-on-quality-performance-and-accountability-in-higher-education

management (NPM) (Ferlie, Musselin, \& Andresani, 2008; Hood, 2007). Forces for and against rankings have spawned a multiplicity of alternatives but arguably this simply reflects their significance as market leaders.

\section{Public policy implications of Rankings for Quality, Performance and Accountability}

Traditionally, defining and maintaining quality was accounted for and dealt with within the university, guided by norms of peer review. This practice has been a cornerstone of the academy since the $17^{\text {th }}$ century, and was based on the idea that only those within a given scientific discipline possess sufficient expertise to make judgements on the output and activity of their peers, through the "principle of mutual judgement by informed specialists" (Becher, 1989). Beginning in the late $20^{\text {th }}$ century, massification and globalisation began to alter the relationship between higher education and the state (Dill \& Beerkens, 2010, p. 4). Global competitiveness and the importance of human capital elevated the importance of higher education, driving its continual expansion and associated research, development and innovation (RDI), whilst amplifying differences between the knowledge-producing capacity and capability of different universities and their respective countries. This has become more significant in response to the lingering social and economic effects of the 2008 global financial crisis - leading to political and public support for closer scrutiny and greater steerage and monitoring.

Accountability is "the obligation to report to others, to explain, to justify, to answer questions about how resources have been used, and to what effect" (Trow, 1996). Espeland and Sauder $(2016,20)$ record the early roots of accountability in classical Athens which "mandated visibility, rectitude, and the participation of citizens". More recently, public accountability has become an issue associated with the "ever increasing complexity of governance" (Bovens et al., 2014, p. 16), as well as broader concerns about elites and the misuse of public funds, "fuelled by scandal and perceived misuse of authority in both the private and public sectors" (Leveille, 2013, p. 6). These concerns reflect shifts from government with direct intervention to more indirect forms of governance (Erkkilä, 2007), accompanied by a shift in the locus of power, and a change in the nature of trust between different sectors of society. At the supranational level, it has become integral to good governance. The 2001 OECD Governance in the 21 $1^{\text {st }}$ Century (Dubnick, 2014, p. 34; OECD, 2001) noted the significance of accountability in terms of good governance. Subsequently, Modernising Government: The Way Forward (OECD, 2005) placed accountability centrestage, as did the United Nations' Unlocking the Human Potential for Public Sector Performance (2005). National examples include Austria's Decentralisation and Accountability (2006), the United Kingdom's Accountability: Adapting to Decentralisation (2011), and the renaming of the U.S. "General Accounting Office" to the "Government Accountability Office" in 2004.

With respect to higher education, accountability speaks to issues of 
Hazelkorn, E., Coates, H. and McCormick, A.C. (Eds.) (2018) Research Handbook on Quality, Performance and Accountability in Higher Education, Edward Elgar Publishing. http://www.eelgar.com/shop/research-handbook-on-quality-performance-and-accountability-in-higher-education

responsibility to the public for quality. It is about meeting the needs of students, society and government. It is about the effectiveness and performance of colleges and universities as well as their transparency of their efforts. Accountability is about higher education serving the public interest and about higher education as a public trust (Eaton, 2016, p. 325).

In essence it is about the social contract between higher education and the "society of which it is a part" (Zumeta, 2011, p. 134), and the extent to which that bargain is upheld and interests balanced especially in the context of myriad stakeholders (Ferlie et al., 2008). At a time of broader trends towards enhanced democratic governance and political accountability (Lijphart, 1999, p. 279), there are several reasons why there has been growing emphasis on accountability. These include, inter alia: funding pressures in an era of near-universal participation and shrinking budget allocations; the quality of graduates and employability concerns; the value, impact and contribution of RDI; and the overall status of higher education given its significance for national positioning and global competitiveness. As a result, a whole set of concepts and processes, such as quality assurance, accreditation, audit, benchmarking, transparency instruments and qualification frameworks - to name just some - have emerged, with significant differences and approaches from country to country (Gallagher, 2010; Salmi, 2015). It is within this wider context that the influence and impact of global rankings should be seen.

Comparison and benchmarking - using a preponderance of quantitative indicators in a variety of "governance indices" - has been a growing part of public policy across many sectors, including health and crime, to drive, monitor and evaluate behaviour and outcomes (Erkkila \& Piironen; Sauder \& Espeland, 2009, 64). The OECD began compiling statistical information shortly after it superseded the Organization for European Economic Cooperation (OEEC) in 1961. It "collected cross-national data to identify long-term labour market needs, especially in the areas of science and technology" (Henry, Lingard, Rizvi, \& Taylor, 2001, 85); country reviews served a similar purpose. The Frascati Manual, first developed in 1963, became the international standard for R\&D statistics across OECD countries and around the world (OECD, 1980), and laid the basis for the biannually published OECD Main Science and Technology Indicators since 1981, drawing on the Science Citation Index and Social Sciences Citation Index (Jacso, 2010). UNESCO has been pivotal in this arena also, involved in establishing the International Standard Classification of Education (ISCED) framework in 1976, and subsequently in identifying appropriate indicators (see chapters in this volume by Martin and Varghese). Since then, big data and data analytics have become significant drivers and tools of/for higher education (e.g. institutional and student activity) and research (e.g. performance and productivity) (Daniel, 2015; Orr, 2004), in turn fuelling the growth of an extensive HE-knowledge intelligence industry (Olds, 2012). 
Hazelkorn, E., Coates, H. and McCormick, A.C. (Eds.) (2018) Research Handbook on Quality, Performance and Accountability in Higher Education, Edward Elgar Publishing. http://www.e-

elgar.com/shop/research-handbook-on-quality-performance-and-accountability-in-higher-education

The OECD International Indicators and Evaluation of Educational Systems (INES) project paved the way for Education at a Glance, beginning 1991. In 2000, the Program for International Student Assessment (PISA) began. Its success, alongside growing criticism of global rankings during the mid-2000s, spurred thinking around the necessity to develop a similar instrument for higher education. In 2008, the first round of PIACC - the Survey of Adult Skills - began, in addition to a series of feasibility studies for an Assessment of Higher Education Learning Outcomes (AHELO). An objective for the latter was the desire to establish international benchmarking of educational outcomes which could fill the existing void and consequently enhance, if not overtake, growing enthusiasm for rankings. However, a combination of criticism from the academy and other issues led to the termination of that project. After several years' absence from this field, the OECD returned to higher education benchmarking in 2016 when it launched its system benchmarking project. By focusing on "systems" rather than "institutions", the OECD hopes to overcome earlier objections while replicating the policy value of PISA. UNESCO and the EU have pursued similar initiatives (Martin \& Sauvageot, 2011; Bonaccorsi et al., 2010), the latter having expanded its Eurostat capacity under the auspices of the European Tertiary Education Register (ETER). ${ }^{2}$

In Europe, higher education was included in the 1957 Treaty of Rome, the treaty that founded the European Economic Community, and would become increasingly central in succeeding years. Establishment of the European University was part of the Euratom Treaty in 1967; joint study programmes began in 1973 were boosted by the Erasmus Study Mobility programme in the 1980s. The Sorbonne Declaration of 1998, which triggered the Bologna Process, was predicated on the free movement of students, faculty and workers across national boundaries. However, mobility required trustworthy information with the assurance that student/graduate performance and credentials would be recognised in other parts of Europe (Hazelkorn, 2012a). Key enablers followed, including the European Qualifications Framework and the European Standards and Guidelines (ESG) which assured "readability" across diverse credentials and recognition of credits. These initiatives have help create a "meta-structure" (Maassen \& Stensaker, 2011) for cross-national comparability.

The U.S. has had long experience of government data collection, and accreditation arrangements. The Bureau of Education began issuing reports on individual academic institutions in the 1870s, and the first accreditation agencies were established around 1900. This led to a process by which standards were established and institutions accredited in the wake of massifcation post-WW2 (El-Khawas, 2001). By mid-20 th century, the highly developed market nature of U.S. higher education, coupled with high levels of geographic mobility and social aspiration, revealed a gap left by insufficient federal data/information and oversight. The Spellings Commission in 2006 urged new accountability measures based on "better data about real performance and lifelong working and learning ability" 
Hazelkorn, E., Coates, H. and McCormick, A.C. (Eds.) (2018) Research Handbook on Quality, Performance and Accountability in Higher Education, Edward Elgar Publishing. http://www.e-

elgar.com/shop/research-handbook-on-quality-performance-and-accountability-in-higher-education

(Commission on the Future of Higher Education, 2006). More recently, concerns about rising costs, poor educational outcomes and career prospects - heightened by controversial practices by for-profit providers - have led to calls to "strengthen [...] accountability for students and taxpayers" (Carter, 2016), and review the accreditation system.

The first college rankings developed in the U.S. sought to provide information to the demand-side, namely for parents and students, in contrast to previous academic or state modes of information collection (Usher, 2016). This has been replicated the global level. Responding to twin drivers of globalisation and accountability, global rankings have changed the discourse around quality and performance by formally highlighting the internationalisation of higher education, its products (graduates and knowledge) and services. In contrast to domestic rankings, which were popular with the wider public from that start, global rankings' consumers are policymakers and the media. By holding up a mirror to universities and nations, they have called into question many assumptions and self-perceptions of excellence. More than this, they have done so by operating outside traditional structures, giving the impression of independence. As such, they have come to fill a gap in the global knowledge intelligence ecosystem, becoming one of the "missing institutions" of globalisation (Nayyar, 2002).

\section{Implications of Rankings for Higher Education Institutions}

HEls have traditionally focused on undergraduate students and, the needs of their proximate town and region (with the advent of civic and land grant universities). Today, they compete nationally, and increasingly internationally. In many cases, they are in "cutthroat competition for students and financial resources" (Brewer, Gates A., \& Goldman, 2002). At the same time, governance arrangements are changing; universities are being granted more self-governing authority and decision-making arrangements in return for greater public accountability (Aghion, Dewatripont, Hoxby, Mas-Colell, \& Sapir, 2009). Thus, leaders are required to be both academically smart and strategically savvy, understand trends and risks, manage and steer the institution efficiently and effectively, position the university within the broader HE landscape, boost the university's reputation and status, and remain attractive and sustainable in the face of mounting challenges.

Effective leadership and management carry requirements for unprecedented levels of professional expertise and training, and institutional capacity and systems to underpin strategic decision-making and monitor and evaluate university performance. Universities are also required to provide common national data about students and research, and other matters (Huisman, Hoekstra, \& Yorke, 2015; Mathies \& Välimaa, 2013). Institutional research (IR) has been an evolving field of "organisational intelligence" (Terenzini, 1993); European HEls are only beginning to develop such capacity. Rankings have become one of the key technologies of management and competition, transforming "how actors make decisions, do their jobs, and think about their schools" (Sauder \& Espeland, 2009). They 
Hazelkorn, E., Coates, H. and McCormick, A.C. (Eds.) (2018) Research Handbook on Quality, Performance and Accountability in Higher Education, Edward Elgar Publishing. http://www.e-

elgar.com/shop/research-handbook-on-quality-performance-and-accountability-in-higher-education

have succeeded in taking the relatively mundane function of data collection and analysis out of the back-office, and placing it at the centre of strategic decision making and performance measurement.

While many university leaders claim they do not over-emphasize rankings, they are conscious of their influence on stakeholders. Attitudes are aligned with strategic ambition and stakeholder views rather than simply institutional mission. $84 \%$ of HEls surveyed in 2014 said they had a formal process for reviewing their institutional position, usually via a committee chaired by their Vice-Chancellor/President (41\%) although in $18 \%$ of case this was undertaken by the Governing Authority (Hazelkorn, 2015). A European survey showed $85 \%$ respondents saying rankings were reviewed by the rector or institutional board (Hazelkorn et al., 2014). Of the latter, 54\% said at least one person at institutional level monitored the university's position in the rankings, while $33 \%$ said they had a specialist unit; one university referred to this as its "nut cracker group".

These experiences suggest microscopic interrogation of data is now routinely used to monitor performance regardless of whether the institution features in rankings. While there is considerable evidence of universities making significant changes to better align themselves with rankings, HEls are also increasingly sophisticated, using rankings as one source rather than the source of information.

\section{Emerging Futures: Alternative Rankings and Alternatives to Rankings}

The response to rankings has led to a proliferation of imitators around the world (Usher, 2016, pp. 30-50). Their popularity highlights the importance of comparability and benchmarking as general principles, coupled with the desire to make judgements on the performance, contribution and value of higher education. Rankings are also part of wider conversations about the role of transparency in higher education (Coates, 2017).

Traditionally, assessing quality has been a qualitative exercise overseen by peer or expert review but this has now insufficient. Usage of quantitative data, which ipso facto appears value-free, has helped legitimise rankings. They have relied primarily on easily accessible research data, and various input measurements, e.g. student entry, academic qualifications, budget/income, library resources, and reputation. Under the influence of the European Bologna Process, the focus has shifted towards learning outcomes and the student experience. Discussion about the "private" and "public" good roles of higher education has turned attention to impact, benefit and relevance.

Over the years, a growing number of new rankings have emerged developed by existing or competitor ranking organisations, and alternatives to rankings by governments and their agencies, higher education organisations, and others. Their appearance speaks to rankings' popularity and usefulness, their point of departure as "a source of indicators for an indicator system" (Martin \& Sauvageot, 2011), as well as response to criticism about shortcomings in 
Hazelkorn, E., Coates, H. and McCormick, A.C. (Eds.) (2018) Research Handbook on Quality, Performance and Accountability in Higher Education, Edward Elgar Publishing. http://www.e-

elgar.com/shop/research-handbook-on-quality-performance-and-accountability-in-higher-education

methodology, choice of indicators and inadequate world-region representation. This section looks briefly at some examples.

- Rankings

Initially perceived as a tool for students and their parents, the audience for rankings has expanded considerably to include government, policymakers, employers, alumni, investors, industrial partners, and the media. Over the years, the number of rankings has increased, and world regions extended. Times Higher Education (THE) and $Q S$ have introduced new rankings by (i) region, (ii) HEI age, and (iii) subject/discipline field. ARWU has introduced subject-based rankings. U.S. News and World Report, which dominated the U.S. since the 1980s, has expanded into the MENA region as well as developing a global ranking.

In response to criticism that the rankings are narrowly focused on research, THE and QS are both developing proxy indicators for teaching \& learning, employability, engagement and entrepreneurship. U-Multirank pioneered the concept of multi-dimensionality to allow different users to identify the most appropriate indicators for their own purposes. This means that does not produce a single ordinal ranking. Despite this characteristic being the source of much criticism about major rankings, U-Multirank has failed to develop a global following. There have also been attempts to measure entire higher education systems, such as that initially proposed by the Lisbon Council, a Brussels-based think-tank (Ederer, Schuller, \& Willms, 2008), and furthered by Universitas $21 .^{3}$

There are almost 200 different national rankings developed and operated by governments/government agencies, as well as media groups and other organisations. The U.S. College ScoreCard ${ }^{4}$ (since 2015) provides data on cost, graduation rates and salary. The UK government introduced the Teaching Excellence Framework (TEF) ${ }^{5}$ as a sister to the Research Excellence Framework (REF). Strictly speaking neither is a ranking but the former toyed with the idea of being organised as such, and the latter uses Olympic-type medals to differentiate performance. There are also a growing range of specialist rankings, inter alia, Green Metric launched in 2010 which measures conditions and policies related to sustainability", Washington Monthly College Rankings since 2005 assesses "schools based on what they are doing for the country" 7 , and Reuters Most Innovative University ${ }^{8}$ rankings launched in 2014 emphasizes patent filings and commercializing its discoveries. ${ }^{9}$

These examples highlight the growing number of players now involved in the rankings game, including supra-national governments, national governments, commercial companies, and higher education organisations. But it also signals wider application. ARWU has created the Global Research University Profiles (GRUP); Thomson Reuters has Global Institutional Profiles, and Elsevier has University Rankings Research Performance Report. Both THE (2014) and U-Multirank publicise the comprehensiveness of their database, with the latter claiming it has the "largest international database on higher education in the 
Hazelkorn, E., Coates, H. and McCormick, A.C. (Eds.) (2018) Research Handbook on Quality, Performance and Accountability in Higher Education, Edward Elgar Publishing. http://www.e-

elgar.com/shop/research-handbook-on-quality-performance-and-accountability-in-higher-education

world". ${ }^{10}$ Moreoso, these developments point to the growing expanse and influence of the global HE intelligence business, providing a rich vein of monetised information.

- Profiling

In 1973, the Carnegie Commission on Higher Education developed a classification of U.S. colleges and universities to support its programme of research and policy analysis. Known as the Carnegie Classification System it differentiated HEls according to doctoral-granting, comprehensive, liberal arts, two-year, professional or specialist, and tribal/native American. Updated in 2005, and again in 2010, the new system introduced characteristics such as enrolment profile, size and settings, and community engagement to overcome being interpreted as a ranking, and perversely driving institutional behaviour (McCormick \& Zhao, 2005; see also chapter in this volume by Borden et al).

Its overall success as a method to characterise institutions influenced the EU which was unhappy with global rankings not least because of Europe's poor showing. They were also keen to emphasize greater differentiation by institutional mission in the belief that European higher education was "too fragmented", leading "to a good average level, but...[failing] to enable enough world-class research" (European Commission, 2006). Compared with only about 200 research-intensive universities in the U.S., Europe has about 4,000 universities each of which claim or want to be research-intensive (Commission, 2011; Hazelkorn \& Ryan, 2013).

In response, the EU created U-Map as a "profiling" tool. ${ }^{11}$ It developed a set of indicators, much broader than either rankings or Carnegie, with results produced as a spider chart showing visual differences between institutions (Hazelkorn, 2013). Over the years, several countries have launched their own versions, including Ireland, Norway and Australia (HEA, 2014). U-Map paved the way for U-Multirank.

- Scorecards and Websites

To make data more widely available, some governments have decided to develop scorecards and websites (Coates, 2017 pp. 288-289). Essentially, these are large-scale databases which enable students and parents, and other users, to access basic data about academic qualifications, student performance and outcomes, costs, etc. The aforementioned College Scorecard ${ }^{12}$ is part of this growing "family" of on-line instruments (Zhou, 2015). Other governments have similarly tools, e.g. the UK (Unistats ${ }^{13}$ ), Australia $\left(\mathrm{QILT}^{14}\right)$ and Catalonia (Winddat ${ }^{15}$ ).

The UK consumer magazine Which? launched their own guide to UK universities and a very small number of university courses in 2011, noting that with the increase in student fees in England people would be spending or getting into debt to the tune of $f 27 \mathrm{k}$ for a 3-year degree (Boffey, 2011). Which? aggregated league table results from The Times, The Guardian and The Complete University Guide, but their webpage also noted other factors 
Hazelkorn, E., Coates, H. and McCormick, A.C. (Eds.) (2018) Research Handbook on Quality, Performance and Accountability in Higher Education, Edward Elgar Publishing. http://www.e-

elgar.com/shop/research-handbook-on-quality-performance-and-accountability-in-higher-education

which they suggested potential students should keep in mind, such as safety, gayfriendliness, and green-ness (Hughes, 2016). StudyAdvantage, ${ }^{16}$ an "international student storytelling portal where prospective students come to be inspired", publishes 'listicles' in the style of popular websites such as Buzzfeed.

- Social Networking

Social networking is fast emerging as a powerful instrument for gathering and disseminating information about higher education. Traditionally, students passed on information about colleges and teachers they liked (or not) through sites such as "Rate my Professor"17. Linkedln takes advantage of crowd-sourcing from its over 400million self-selected users worldwide to create a ranking of universities based on career outcomes (Kapur, Lytkin, Chen, Agarwal, \& Perisic, 2016). While not as comprehensive as other rankings, it has successfully taken "postgraduate opportunities into consideration; something that's quite rare in university rankings" (Ryan, 2014). Bought by Microsoft for $\$ 26$ billion, it signals future potential (Feller, 2016).

\section{Conclusion}

This chapter has discussed rankings in the context of the broader accountability agenda. It argues that increasing emphasis on higher education quality, performance and accountability should be seen within the context of i) wider concerns about "good" governance, and ii) national competitiveness at a time of accelerating globalisation and correspondingly higher education's ability to attract mobile capital and talent. We usually look upon rankings, for good or ill, as a technical instrument influencing and impacting higher education decision-making and academic behaviour, but their significance extends beyond these attributes.

Rankings have provoked debate about quality, but that debate is now moving beyond rankings (Coates, 2017). No doubt, international higher education, operating in a globalised world economy, requires the appropriate underpinning architecture. Accordingly, there is a growing attraction of "simple, readily comparable quantitative propositions" alongside "various forms of aggregated numeric representations [which] facilitate the ability of organizations and individuals to navigate complex and disorientating situations" (Rottenburg \& Merry, 2015, p. 3). In coming years, we are likely to see growing demand for a "high-quality and publicly accessible database of relevant basic data that can be used for meaningful benchmarking of higher education institutions" (O'Malley, 2016). Contestation about the limitations of rankings, with their overemphasis on research and elite universities, is driving more sophisticated methodologies, from governments and international organisations - to focus on student experience, learning gain and added value, engagement and "third mission", etc. - many of which are discussed by other authors in this volume. In 
Hazelkorn, E., Coates, H. and McCormick, A.C. (Eds.) (2018) Research Handbook on Quality, Performance and Accountability in Higher Education, Edward Elgar Publishing. http://www.e-

elgar.com/shop/research-handbook-on-quality-performance-and-accountability-in-higher-education

the meantime, data ownership will become a topical and controversial subject as (commercial) organisations are busily monetising the data they have acquired. As evident in other global sectors, consolidation is becoming evident with companies such as Reuters and Elsevier moving from publishing to monetised data, and Microsoft and Linkedln moving into rankings. At the same time, other evidence suggests open-access data combined with social networking has the potential to dramatically transform how higher education quality and performance is assessed and interpreted in the future - placing such information in the hands of students and other stakeholders, and beyond the reach of the academy and governments.

\section{Bibliography}

Aghion, P., Dewatripont, M., Hoxby, C. M., Mas-Colell, A., \& Sapir, A. (2009). The Governance and Performance of Research Universities: Evidence from Europe and the U.S. (No. 14851). Cambridge, Massachusetts.

Altbach, P. G. (2011). "The Past, Present, and Future of the Research University." In P. G. Altbach \& J. Salmi (Eds.), The Road to Academic Excellence. The Making of World-Class Research Universities (pp. 11-32). Washington, D.C. : The World Bank .

Austrian Federal Chancellery. (2006). Decentralisation and Accountability as focus of public administration modernisation. Vienna: Austrian Federal Chancellery.

Baty, P. (2016a). "INSIDE "THE" RANKING. Global Competitiveness and International Visibility." Humboldt Ferngespräche, (9).

Baty, P. (2016b, September). "THE World University Rankings 2016-2017 passes independent audit." Times Higher Education.

Becher, A. (1989). Academic tribes and territories (2nd ed.). Buckingham, UK: SRHE and Open University Press.

Bekhradina, B. (2016). International university rankings: For good or ill? (HEPI Report No. 89). Oxford: Higher Education Policy Institute.

Boffey, D. (2011). "Which? magazine to test value of degrees." The Guardian, October 22.

Bonaccorsi, A., Brandt, T., De Filippo, D., Lepori, B., Molinari, F., Niederl, A., Schmoch, U., Schubert, T., Slipersaeter, S. (2010). Feasibility Study for Creating a European University Data Collection (EUMIDA): Final Study Report. Brussels: The European Commission.

Borden, V. M. H. (2011). Suggestions for Improvements to the Student-to-Faculty Ratio in IPEDS. Suggestions for Improvements to the Student-to-Faculty Ratio in IPEDS. Washington D.C.: National Center for Education Statistics.

Bovens, M., Goodin, R. E., Schillemans, T., Bovens, M., Schillemans, T., \& Goodin, R. E. (2014). "Public Accountability." In M. Bovens, R. E. Goodin, \& T. Schillemans (Eds.), The Oxford Handbook of Public Accountability (pp. 1-20). Oxford: Oxford University Press. http://doi.org/10.1093/oxfordhb/9780199641253.013.0012 
Hazelkorn, E., Coates, H. and McCormick, A.C. (Eds.) (2018) Research Handbook on Quality, Performance and Accountability in Higher Education, Edward Elgar Publishing. http://www.eelgar.com/shop/research-handbook-on-quality-performance-and-accountability-in-higher-education

Bowman, N. A., \& Bastedo, M. N. (2011). "Anchoring effects in world university rankings: exploring biases in reputation scores." Higher Education. http://doi.org/10.1007/s10734-010-9339-1

Brewer, D. J., Gates, S. M., \& Goldman, C. A. (2002). In Pursuit of Prestige: Strategy and Competition in U.S. Higher Education. Rand. New Brunswick and London: Transaction Publishers. Retrieved from http://www.rand.org/pubs/drafts/DRU2541.html

Carter, J. (2016). "Graduation rates at core of potential accreditation overhaul." Education Dive, September 22.

Cloud, M., \& Shepherd, G. B. (2006). Law Deans in Jail (Research Paper No. 12-199). Legal Studies Research Paper Series.

Coates, H. (2017). "Reporting alternatives: Future transparency mechanisms for higher education." In E. Hazelkorn (Ed.), Global Rankings and the Geopolitics of Higher Education (pp. 277-294). Abingdon and New York: Routledge.

Commission on the Future of Higher Education. (2006). A Test of Leadership. Charting the Future of U.S. Higher Education: A Report of the Commission Appointed by Secretary of Education Margaret Spellings. Washington D.C.: U.S. Department of Education.

Daniel, B. (2015). "Big Data and analytics in higher education: Opportunities and challenges." British Journal of Educational Technology, 46(5), 904-920. http://doi.org/10.1111/bjet.12230

Dill \& Beerkens, M.., D. D. (2010). "Reflections and conclusions." In D. D. Dill \& M. Beerkens (Eds.), Public policy for academic quality. Analyses of innovative policy instruments (pp. 313-335). Dordrecht: Springer.

Dubnick, M. J. (2014). "Accountability as a Cultural Keyword." In M. Bovens, R. E. Goodin, \& T. Schillemans (Eds.), The Oxford Handbook of Public Accountability (pp. 23-38). Oxford: Oxford University Press. http://doi.org/10.1093/oxfordhb/9780199641253.013.0017

Eaton, J. S. (2016). "The quest for quality and the role, impact and influence of supranational organisations." In E. Hazelkorn (Ed.), Global Rankings and the Geopolitics of Higher Education (pp. 324-338). London and New York: Routledge.

Ederer, P., Schuller, P., \& Willms, S. (2008). "University Systems Ranking: Citizens and Society in the Age of Knowledge, The Lisbon Council Policy Brief." Brussels: The Lisbon Council.

El-Khawas, E. (2001). Accreditation in the USA: origins, developments and future prospects. Improving the managerial effectiveness of higher education institutions. Paris: UNESCO. http://unesdoc.unesco.org/images/0012/001292/129295e.pdf.

Erkkilä, T. (2007). "Governance and accountability - a shift in conceptualisation." Public Administration Quarterly, 1-38.

Erkkilä, T., \& Piironen, O. (2009). "The Iron Cage of Governance Indicators." In Raymond W. Cox (Ed.), Ethics and Integrity in Public Administration. Concepts and Cases (pp. 125145). Armonk, New York, London, UK: M. E. Sharpe. 
Hazelkorn, E., Coates, H. and McCormick, A.C. (Eds.) (2018) Research Handbook on Quality, Performance and Accountability in Higher Education, Edward Elgar Publishing. http://www.e-

elgar.com/shop/research-handbook-on-quality-performance-and-accountability-in-higher-education

Espeland, W. N., \& Sauder, M. (2007). "Rankings and Reactivity: How Public Measures Recreate Social Worlds." American Journal of Sociology, 113(1), 1-40. http://doi.org/10.1086/517897

Espeland, W. N., \& Sauder, M. (2016). Engines of Anxiety. Academic Rankings, Reputation and Accountability. New York: Russell Sage Foundation.

European Commission. (2006). "Frequently Asked Questions : why European higher education systems must be modernised?" Brussels: European Commission.

European Commission. (2011). Supporting growth and jobs - An agenda for the modernisation of Europe's higher education systems. Luxembourg: Publications Office of the European Union. http://doi.org/10.2766/17689

Feller, Grant. (2016). This Is The Real Reason Microsoft Bought Linkedln. Forbes, June 14.

Ferlie, E., Musselin, C., \& Andresani, G. (2008). "The steering of higher education systems: a public management perspective." Higher Education, 56(3), 325-348. http://doi.org/10.1007/s10734-008-9125-5

Gallagher, M. (2010). The Accountability for Quality Agenda in Higher Education. Canberra: Group of 8. Retrieved from https://go8.edu.au/publication/accountability-qualityagenda-higher-education

Hazelkorn, E. (2012a). "European "transparency instruments": Driving the Modernisation of European Higher Education." In S. P. Scott, A. Curaj, L. Vlăsceanu, \& L. Wilson (Eds.), European Higher Education at the crossroads: between the Bologna Process and national reforms (Vol. 1). Dordrecht: Springer.

Hazelkorn, E. (2013). "Europe Enters the College Ranking Game." Washington Monthly, September/October.

Hazelkorn, E. (2015). Rankings and the Reshaping of Higher Education (2 ${ }^{\text {nd }}$ Ed.). Basingstoke: Palgrave Macmillan. http://doi.org/10.1057/9780230306394

Hazelkorn, E., \& Ryan, M. (2013). "The Impact of University Rankings on Higher Education Policy in Europe: A Challenge to Perceived Wisdom and a Stimulus for Change." In Pavel Zgaga, U. Teichler, \& J. Brennan (Eds.), The Globalization Challenge for European Higher Education: Convergence and Diversity, Centres and Peripheries (pp. 79-99). Frankfurt: Peter Lang.

Henry, M., Lingard, B., Rizvi, F., \& Taylor, S. (2001). The OECD, Globalisation and Education Policy. Oxford: IAU Press/Pergamon/Elsevier.

Holmes, R. (2017). "Trinity College Shoots Itself in the Other Foot." University Rankings Watch blog.

Hood, C. (2007). "Public Service Management by Numbers: Why Does it Vary? Where Has it Come From? What Are the Gaps and the Puzzles?" Public Money and Management, 27(2), 95-102. http://doi.org/10.1111/j.1467-9302.2007.00560.x

Hughes, R. (2016). "Alternative university league tables." Retrieved April 25, 2017, from http://university.which.co.uk/advice/choosing-a-course/university-league-tables- 
Hazelkorn, E., Coates, H. and McCormick, A.C. (Eds.) (2018) Research Handbook on Quality, Performance and Accountability in Higher Education, Edward Elgar Publishing. http://www.eelgar.com/shop/research-handbook-on-quality-performance-and-accountability-in-higher-education

alternative

Huisman, J., Hoekstra, P., \& Yorke, M. (2015). "Institutional Research in Europe: A view from the European Association for Institutional Research Jeroen." In K. L. Webber \& A. J. Calderon (Eds.), Institutional Research and Planning in Higher Education. Global Contexts and Themes (pp. 58-70). New York and London: Routledge.

Jacso, P. (2010). "The impact of Eugene Garfield through the prism of Web of Science." Annals of Library and Information Studies, 57(September), 222-247.

Kapur, N., Lytkin, N., Chen, B.-C., Agarwal, D., \& Perisic, I. (2016). "Ranking Universities Based on Career Outcomes of Graduates." In 22nd ACM SIGKDD Conference on Knoweldge Discovery and Data Mining. San Francisco. http://doi.org/10.1145/2939672.2939701

Leveille, D. E. (2013). "Accountability in Postsecondary Education Revisited." CSHE Research \& Occasional Paper Series, 13(9).

Lijphart, A. (2012). Patterns of Democracy (Revised). New Haven, CT: Yale University Press.

Maassen, P., \& Stensaker, B. (2011). "The knowledge triangle, European higher education policy logics and policy implications." Higher Education, 61(6), 757-769. http://doi.org/10.1007/s10734-010-9360-4

Martin, M., \& Sauvageot, C. (2011). Constructing an indicator system or scorecard for higher education. Paris: UNESCO. Retrieved from http://www.uis.unesco.org/Library/Documents/constructing-indicator-systemscorecard-higher-education-2011-en.pdf

Mathies, C., \& Välimaa, J. (2013). "Is There a Need for a European Institutional Research?" Tertiary Education and Management, 19(1), 85-96. http://doi.org/10.1080/13583883.2012.747558

McCormick, A. C., \& Zhao, C.-M. (2005). "Rethinking and Reframing the Carnegie Classification." Change, September, 51-57. Retrieved from http://classifications.carnegiefoundation.org//downloads/rethinking.pdf

Myers, L., \& Robe, J. (2009). College Rankings. History, Criticism and Reform. Center for College Affordability and Productivity. Washington D.C.: Center for College Affordability and Productivity. Retrieved from http://www.eric.ed.gov/ERICWebPortal/recordDetail?accno=ED536277

Nayyar, D. (2002). "The Existing System and the Missing Institutions." In D. Nayyar (Ed.), Governing Globalization: Issues and Institutions (pp. 356-384). Oxford: Oxford University Press.

O’Malley, B. (2016, January). "Coimbra Group tells U-Multirank to revamp its data." University World News.

OECD. (1980). Measuring Science, Technology, and Innovation. Paris: OECD. http://doi.org/10.5465/AMR.1980.4288982

OECD. (2001). Governance in the 21st century. Paris: OECD. 
Hazelkorn, E., Coates, H. and McCormick, A.C. (Eds.) (2018) Research Handbook on Quality, Performance and Accountability in Higher Education, Edward Elgar Publishing. http://www.e-

elgar.com/shop/research-handbook-on-quality-performance-and-accountability-in-higher-education

OECD. (2005). Modernising Government: The Way Forward. Paris: OECD. Retrieved from http://www.oecd.org/gov/modernisinggovernmentthewayforward.htm

Olds, K. (2012). "Why now? Making markets via the THE World Reputation Rankings." Inside Higher Ed. Retrieved from http://www.insidehighered.com/blogs/globalhighered/whynow-making-markets-world-reputation-rankings

Orr, D. (2004). "Research Assessment as an Instrument for Steering Higher Education - A Comparative Study." Journal of Higher Education Policy and Management, 26 (3)(3), 345-362. http://doi.org/10.1080/1360080042000290195

Pike, G. R., Kuh, G. D., McCormick, A. C., Ethington, C. A., \& Smart, J. C. (2011). "If and When Money Matters: The Relationships Among Educational Expenditures, Student Engagement and Students' Learning Outcomes." Research in Higher Education, 52(1), 81-106. http://doi.org/10.1007/s11162-010-9183-2

Quacquarelli Symonds World University Rankings. (2017). QS University Rankings. Retrieved From https://www.topuniversities.com/university-rankings

Rottenburg, R., \& Merry, S. E. (2015). "A world of indicators: the making of governmental knowledge through quantification." In R. Rottenburg, S. E. Merry, S.-J. Park, \& J. Mugler (Eds.), The World of Indicators: The Making of Governmental Knowledge Through Quantification (pp. 1-33). Cambridge: Cambridge University Press.

Ryan, L. (2014). "Do the LinkedIn university rankings really matter?" Terminal Four blog. Retrieved from https://www.terminalfour.com/blog/posts/do-the-linkedin-universityrankings-really-matter.html

Salmi, J. (2015). Is Big Brother Watching You? The Evolving Role of the State in Regulating and Conducting Quality Assurance. CHEA/CIQG Publication Series (Vol. 2).

Snyder, T. D. (1993). 120 years of American education: A statistical portrait. Washington D.C.: National Center for Education Statistics.

Standards \& Poor. (2016). "General Criteria: Methodology: Not-For-Profit Public And Private Colleges And Universities."

Stanley, G. (2012). "Challenges in the Quest to Create Global Qualifications and Standards are Driving Change in Education Systems." In W. Bienkowski, J. C. Brada, \& G. Stanley (Eds.), The University in the Age of Globalization. Rankings, Resources and Reforms (pp. 3-25). Basingstoke, UK: Palgrave Macmillan UK.

Terenzini, P. T. (1993). "On the nature of institutional research and the knowledge and skills it requires." Research in Higher Education, 34(1), 1-10.

THE World University Rankings. (2014, November 19). "Times Higher Education announces reforms to its World University Rankings". Times Higher Education World University Rankings. Retrieved from http://www.timeshighereducation.co.uk/world-universityrankings/news/times-higher-education-announces-reforms-to-world-universityrankings

Times Higher Education. (2017). Times Higher Education World University Rankings. Retrieved from https://www.timeshighereducation.com/world-university-rankings. 
Hazelkorn, E., Coates, H. and McCormick, A.C. (Eds.) (2018) Research Handbook on Quality, Performance and Accountability in Higher Education, Edward Elgar Publishing. http://www.eelgar.com/shop/research-handbook-on-quality-performance-and-accountability-in-higher-education

Trow, M. (1996). "Trust, markets and accountability in higher education: A comparative perspective." Higher Education Policy, 9(4), 309-324. http://doi.org/10.1016/S09528733(96)00029-3

U.K. Department for Local Communities and Local Government (2011). Accountability: Adapting to Decentralisation. London: Department for Local Communities and Local Government.

United Nations. (2005). Unlocking the Human Potential for Public Sector Performance. New York: United Nations Department of Economic and Social Affairs.

Usher, A. (2016). "A short global history of rankings." In E. Hazelkorn (Ed.), Global Rankings and the Geopolitics of Higher Education (pp. 23-53). London and New York: Routledge.

Webster, D. S. (1986). Academic Quality Rankings of American Colleges and Universities. Springfield, IL.: Charles C. Thomas.

Zhou, L. (2015). "Obama's New College Scorecard Flips the Focus of Rankings." The Atlantic, September 15.

Zumeta, W. M. (2011). "What Does It Mean to Be Accountable? Dimensions and Implications of Higher Education's Public Accountability." The Review of Higher Education, 35(1), 131-148. http://doi.org/10.1353/rhe.2011.0037

${ }^{1}$ Other well-used rankings inlcude, inter alia: University Ranking by Academic Performance (URAP) from Turkey, the National Taiwan University Rankings, Best Global

Universities from US News, Leiden Rankings and the Round University Rankings from Russia.

${ }^{2}$ http://europa.eu/rapid/press-release MEMO-14-447 en.htm; http://risis.eu/data/eterdataset/

${ }^{3}$ http://www.universitas21.com/article/projects/details/152/u21-ranking-of-nationalhigher-education-systems

${ }^{4}$ https://collegescorecard.ed.gov

${ }^{5}$ http://www.hefce.ac.uk/lt/tef/

${ }^{6}$ http://greenmetric.ui.ac.id

${ }^{7}$ http://washingtonmonthly.com/college_guide

${ }^{8}$ http://www.reuters.com/article/idUSL1N11K16Q20150915

${ }^{9}$ http://www.reuters.com/article/idUSL1N11K16Q20150915

${ }^{10}$ http://www.umultirank.org/\#!/about/Press\%20Releases/u-multirank-to-release-fourthand-largest-global-university-rankings-yet-new-universities-new-subjects-and-new-

indicators?name=null\&trackType=about\&section=undefined

11 http://www.u-map.eu

12 https://collegescorecard.ed.gov/

${ }^{13}$ https://unistats.direct.gov.uk/

${ }^{14}$ https://www.qilt.edu.au/ 
Hazelkorn, E., Coates, H. and McCormick, A.C. (Eds.) (2018) Research Handbook on Quality, Performance and Accountability in Higher Education, Edward Elgar Publishing. http://www.eelgar.com/shop/research-handbook-on-quality-performance-and-accountability-in-higher-education

\footnotetext{
${ }^{15} \mathrm{http}: / /$ winddat.aqu.cat/en/

${ }^{16}$ www.studyadvantage.co

${ }^{17}$ http://www.ratemyprofessors.com
} 